\title{
Pre-Service Teacher Education in Times of Crisis
}

\section{Formação inicial de professores em tempos de crise}

Ana Karina de Oliveira Nascimento*

*Universidade Federal de Sergipe (UFS), Aracaju, Sergipe / Brasil

akcoliveira@academico.ufs.br

https://orcid.org/0000-0002-3014-0659

Maria Amália Vargas Façanha**

**Universidade Federal de Sergipe (UFS), Aracaju, Sergipe / Brasil

amaliavargas@academico.ufs.br

https://orcid.org/0000-0001-5606-2583

\author{
Marlene de Almeida Augusto de Souza*** \\ ***Universidade Federal de Sergipe (UFS), Aracaju, Sergipe / Brasil \\ marlene04@academico.ufs.br \\ https://orcid.org/0000-0001-5941-2104
}

\begin{abstract}
No doubt, this is a time of crisis. The impact of COVID-19 on people's lives is tremendous. The pandemic affects human beings in different ways, depending on their place in society, but everybody is somehow affected: in finances, emotions, behaviors, to mention a few. The same is true about education. Institutions, teachers and learners are pushed to debates and changes never considered, which raise a number of uncertainties. Motivated by discussions the authors took part in as teacher educators, a documentary research was conducted, focusing on national and local documents published due to the pandemic. Based on the data collected, in this article we aim at discussing their possible implications for teacher education.
\end{abstract}

KEYWORDS: COVID-19; pre-service teacher education; crisis.

RESUMO: Sem dúvida, este é um momento de crise. O impacto da COVID-19 na vida das pessoas é enorme. A pandemia afeta as pessoas de maneiras diferentes, dependendo do seu lugar na sociedade; mas todas são afetadas, de alguma forma: em finanças, emoções, comportamentos, por exemplo. O mesmo se aplica à educação. Instituições, professores e alunos são levados a debates e mudanças nunca considerados, gerando muitas incertezas. Motivadas pelas discussões das quais as autoras fizeram parte como professoras formadoras, foi realizada uma pesquisa documental com foco em documentos nacionais e 
locais publicados devido à pandemia. A partir dos dados levantados, neste artigo, discutimos as possíveis implicações para a formação inicial de professores em uma universidade federal localizada no nordeste do Brasil.

PALAVRAS-CHAVE: COVID-19; formação inicial de professores; crise.

\section{Introduction}

"Nothing that has been will be again as it was some day."1 These verses have been sung in Brazil since 1983 and they help us think about the ephemerality, temporality, and transience of life. The COVID-19 pandemic, an unknown and aggressive disease that may result in a high death rate due to the lack of specialized professionals and equipment to treat people who are infected, has been showing us, not in a poetic way, that our personal and professional plans, and all our assurances are, in fact, uncertain; and because of that, we may be forced to review them. Due to the pandemic, we are now living physically isolated, and some activities that are not essential are suspended or carried out remotely. Undoubtedly, after around a year, we are still living through a period of crisis. The impacts of COVID-19 on people's lives are huge and physical isolation is just one of them. The pandemic affects human beings in different ways, depending on their status in society, but everyone is definitely affected somehow, whether it is financially or emotionally, to mention some.

The same challenges may be noticed in the educational field. Educational institutions, teachers, students and different segments of society are led to debates and changes that had not been considered yet. As a consequence, we are facing different kinds of uncertainties. We recognize the unpredictability of life, and the need for reviewing what we have been planning. Besides that, we recognize the importance of knowing where we want to go. After all, as said by the Chesire cat, from Alice in Wonderland (CARROLL, 1865 [2007]), it does not matter which path to take if one does not know where to go.

In terms of education, we are responsible for knowing clearly where we want to get to. In education, there are many possible ways to choose,

\footnotetext{
${ }^{1}$ Verses of the song "Wave" composed by Lulu Santos and Nelson Motta. In the original: Nada do que foi será de novo do jeito que já foi um dia. All passages translated from Portuguese into English are the authors' responsibilities.
} 
some of them are shorter, others longer, and some of them may have more or less obstacles. Because of that, when deciding which way we are going, we have to consider some important questions: what kind of education does the chosen way provide? Who are the students we are (not) taking along in this path? How can the length and obstacles of the path interfere and/or limit the access of students who are members of certain groups? Who are the teachers along this path? How do they feel about all that is going on?

Sousa Santos (2020) states that, while there is an invisible virus, there is a "pandemic clarity" that allows us to see (or it compels us to stop pretending we are not seeing) all the inequalities and the social exclusion that are a result of social organizations. This new normal tends to deepen neoconservative and neoliberal ways of governance, which constitute a threat to education, but most importantly, to lives, due to the social inequalities we witness every day, especially in countries such as Brazil. The author also argues that the way we interpret and evaluate these unveiled realities will determine our future. Therefore, we understand the importance of problematizing, in the field of applied linguistics, as language teacher educators, dichotomies that have been part of literacies research, such as: science versus non-science, us versus them, as we understand the intrinsic connection between literacy education to political and ideological aspects, to mention a few.

This article aims to discuss some aspects of this debate, more specifically, the aspects related to higher education, focusing on pre-service teacher education at a Federal University located in northeastern Brazil. To this end, motivated by the discussions in which the authors of this article have taken part as teacher educators, a documentary research was carried out, focusing on national and local documents published due to the pandemic. Based on the analysis of these data we are going to discuss the possible implications for teacher education as a result of the orientations presented on national and local documents due to the pandemic.

\section{What a virus has been teaching us, Brazilians}

As of February 3rd 2021, more than 2 million deaths worldwide due to COVID-19 were reported to the World Health Organization (WHO, 2020a, $2020 \mathrm{~b})$. As it was not previously expected, the virus caught the populations unprepared and thus changed the lives of thousands of people throughout the globe, impacting a big number of people and societies. Still according to 
the WHO, the mostly known and viable strategy to contain the spread of the coronavirus, the virus that causes COVID-19, is through the implementation of social distancing. However, it has been hard to implement it and live with it since it challenges people's necessity to come and go.

As a result of this new requirement, lots of social practices had to be remodeled or even avoided, such as visiting people, family gatherings, business meetings, going shopping at malls, meeting friends and so on. That means different aspects of social life were dramatically changed. As part of our social practices, educational institutions were also affected by this big change. After all, it is in schools, colleges and universities where a big number of people get together in order to learn; and not being allowed to go to these spaces has a tremendous impact on people's lives.

According to Miks and McIlwaine (2020, online) whose text about the impact of the pandemic in education was posted on the United Nations Children's Fund (Unicef) site, in a statement made in April 2020,

the numbers are unprecedented, the implications enormous. As the COVID-19 pandemic has spread across the globe, a majority of countries have announced the temporary closure of schools, impacting more than 91 percent of students worldwide - around 1.6 billion children and young people.

This is happening in many countries around the world. Still according to the aforementioned authors, "by late March, around 95 percent of enrolled children were temporarily out of school due to COVID-19 across Latin America and the Caribbean - more than 150 million children across the region.” (MIKS; MCILWAINE, 2020, online).

A solution found in times of great change has been the adoption of remote classes involving digital technologies. According to Forrest (2020), who conducted an interview with professors Bill Cope and Mary Kalantzis, ${ }^{2}$ this kind of learning in times of social distancing of COVID-19 could

${ }^{2}$ Dr. Bill Cope and Dr. Mary Kalantzis are both professors in the Department of Education Policy, Organization and Leadership at the University of Illinois at Urbana-Champaign, USA. They have extensive research and a number of books published on topics related to literacies, multiliteracies and e-learning. Therefore, they are references in this field of new challenges imposed by digital environments. For more information, see: https:// newlearningonline.com/. Access: Feb. $2^{\text {nd }}, 2021$. 
potentially revolutionize online learning and higher education if learning and platforms started to be conceived as more distributed and collaborative. However, what we have witnessed has been the rapid change from inperson to remote classes due to a necessity imposed by the spread of the coronavirus without much studies, research or thought. It looks like, in order to make remote learning possible, all that is necessary is the adoption of digital technologies. Thus, we have watched computer software, mobile applications and devices starting to be used by some teachers/educational institutions where they had never been considered before as a way to reproduce practices of in-person teaching and learning.

One of the consequences of this situation has been the fact that the teacher's job now requires new practices by both educators (teachers, professors, coordinators, school principals and so on) and students. In Brazil, for example, a research conducted in May 2020 by Nova Escola magazine and published by Bimbati (2020), involving teachers from all over the country, revealed that $30 \%$ of the teachers who were working online considered the experience as terrible. Besides, only $5 \%$ considered the experience as great from the around 8 thousand teachers participating. That is also the case for pre-service teachers and teacher educators, such as the authors of this article.

But how has this situation become a reality in the Brazilian educational context? As we understand applied linguistics involved in a wider social, ideological and political context, we believe it is important for those conducting research on this field of study to question our current position due to the COVID-19 pandemic. First of all, we call attention to the fact that, as it is widely known, the pandemic affects countries and populations differently. Likewise, it is common knowledge how countries from the South tend to suffer more than the ones from the North in many areas, especially health care provision, unemployment, transportation, and most importantly, considering the objective of this article, education. As stated by Sousa Santos (2020, p. 21, our translation):

Any quarantine is always discriminatory, more difficult for some social groups than for others and impossible for a large group of caregivers, whose mission is to make quarantine possible for the entire population. [There are] groups for which quarantine is particularly difficult. These are the groups that have in common a special vulnerability that precedes the 
quarantine and worsens with it. Such groups make up what I call the South. In my view, the South does not designate a geographical space. It designates a political, social and cultural space-time. It is a metaphor for unjust human suffering caused by capitalist exploitation, racial and sexual discrimination. [...] There are many of these social collectives.

Considering that Brazil is part of the Global South, and so are those individuals involved in education in our country, there is no doubt that, together with other groups of workers, teachers are subject to much pressure to go back to work, no matter what this might mean to their lives. This situation is deepened, especially considering the political moment the country is currently facing.

Still in 2018, when the current Brazilian president was running for president, one of his main points addressed during the campaign was how fiercely his government would fight against teachers' indoctrination in educational institutions. After all, according to him, teachers' job is to teach the content and not some sort of ideology, as if there are neutral speeches, acts, attitudes or even teaching. Despite his ideas, or most likely due to that, he was elected and started a battle against teachers and mostly higher education institutions as one of the most important sites of educational indoctrination.

What has been observed is how the government's ideas have been close to what neoconservative, fascist governments are about or the connections to it. For instance, according to Stanley (2018), fascism could be defined as an ideology based on power and loyalty. Taking this general definition, the author claims that there are ten pillars for fascism and discusses each of them in a chapter of the book. They are: 1. A mythic past - which relates to the desire of having a once great past back; 2. Propaganda - through which the idea of news is in fact fake news, anti-corruption is corruption, there is an inversion of facts; 3 . Anti-intellectualism - going against thought and appealing for emotions, especially aiming at the least educated people; 4. Unreality - based on conspiracy theories and an appeal for loyalty no matter what the facts are; 5 . Hierarchy - having the dominant group seen as better than everybody else; 6 . Victimhood - the dominant group is seen as the greatest victims (men over women, whites over blacks and so on); 7. Law and order - which refers to criminalizing the real victims and standing for force and law, as a way to guarantee order; 8. Sexual anxiety 
- relates to the construction of fear around the threat of rape; 9. Sodom and Gomorrah - which is about giving value to what comes from the rural areas as opposed to the city; 10. "Arbeit macht frei" - those part of their selected group are hard workers, the others are, besides lazy, potential criminals.

Considering the objective of this article, we believe the third pillar anti-intellectualism, mentioned by the author - should be analyzed more deeply as it connects directly to the current condition Brazil has been in as a result of the pandemic. Based on fake news and the adoption of an antiintellectual attitude, the Brazilian government has been denying the negative aspects and results of the COVID-19 pandemic through a number of attitudes. Just to mention a few, the country has had three Health Ministers since the beginning of the pandemic, and spent four months (from May to September) with an interim Health Minister in 2020; the president has insisted on classifying the disease as a minor flu; on a national scale, wearing masks is not mandatory due to a law passed by the federal government. As the list could be exhaustive, we decided to mention just these few and invite the readers to think about how they connect to anti-intellectualism. After all, these attitudes prove that the scientific knowledge being produced worldwide has not been taken seriously in the country.

One of the ways anti-intellectualism has been growing strong in Brazil is through actions that seek to delegitimize scientific findings under the argument that everybody has the right to express their opinion, thus freedom of thought and speech has to be guaranteed. What has not been taken into account under this argument is the fact that scientific knowledge does not disregard those rights. But it differs from opinions due to the way knowledge is constructed, considering a methodological basis, analysis, and peer evaluation. After all, when an article is written, it has to be submitted to other scientists who approve or disapprove its publication.

What is a fact, however, is that more than 220 thousand Brazilians have lost their lives due to COVID-19 by the beginning of February 2021. So, no matter how much the government denies it and disregards what scientists have been saying concerning how deadly the virus is, the high numbers of deaths are there to remind us all that we are dealing with a highly dangerous and fatal virus. Despite that, it is easy to find in social media in Brazil, pieces of information that go against what science has thus far found out concerning the coronavirus, inducing Brazilian citizens to accept governmental speeches delivered by the president and his Minister 
of Economy, such as: “The economy cannot stop!"; "'Let's not kill economy otherwise the tragedy will be worse"; "We are sorry for all the deaths but it is everybody's fate"; "T "There will be no money to pay the wages of civil servants". 6

By disseminating speeches such as these ones, the Brazilian government reinforces what we understand as a reference to anti-intellectualism, which ends up sacrificing more lives. Besides that, it reinforces other points such as the one related to public servants as responsible for the crisis and the necessity for teachers to keep on teaching, and even go back to in-person classes despite all the dangers associated with it. All that creates a kind of war against public servants and teachers, which echoes on our society as a whole. As pointed out by Duboc and Ferraz (2018, p. 231), it is the politics of us versus them. According to the authors,

the politics of "us" versus "them" proves to be at stake in recent political decisions. In this respect, the snapshots presented [...] echo this dichotomy inasmuch as they seem to share a common ground based on a revival of homogeneity, normatization, and universalism. [They] reveal that the world has taken dangerous shortcuts when attempting to respond to the new complexities arising in global societies, instead of trying to cope with what or who is different $[\ldots]$. The shortcuts comprise political decisions founded on segregation and exclusion $[\ldots]$.

In terms of the Brazilian educational context, we can think of us, educators, more specifically, pre-service teacher educators, especially the ones in public institutions, versus them, the other workers who need to

\footnotetext{
3 Available at: https://www.gov.br/planalto/pt-br/acompanhe-o-planalto/ noticias/2020/03/economia-nao-pode-parar-diz-bolsonaro-ao-setor-produtivo-brasileiro. Access: Feb. $5^{\text {th }}, 2021$.

${ }^{4}$ Available at: https://exame.com/economia/guedes-diz-que-brasil-ja-estava-decolandoantes-da-crise-do-coronavirus/. Access: Feb. 5 ${ }^{\text {th }}, 2021$.

${ }^{5}$ Available at: https://istoe.com.br/bolsonaro-lamenta-vitimas-de-covid-19-e-ressaltaque-morte-e-o-destino-de-todo-mundo/. Access: Feb. $5^{\text {th }}, 2021$.

${ }^{6}$ Available at: https://economia.uol.com.br/noticias/redacao/2020/05/14/vai-faltardinheiro-para-pagar-servidor-publico-diz-bolsonaro.htm?cmpid=copiaecola. Access: Feb. $5^{\text {th }}, 2021$.
} 
keep working in order to make life financially viable. Likewise, we, school teachers, also need to go back to work so that parents, them, can keep being part of the workforce. All these points have been materialized in educational documents, such as the ones we analyze in the following sections.

\section{A virus and what national education is about}

In this section, we analyze three documents issued by the Education Ministry (MEC) and the National Education Council (CNE): (1) MEC Ordinance No. 343 (BRASIL, 2020a); (2) MEC Ordinance No. 345 (BRASIL, 2020b), (3) CNE / Opinion No. 5/2020 (BRASIL, 2020c). Such documents provide for the suspension of in-person classes, specifically regarding the supervised practices of Teacher Education courses. The analysis will focus on three questions, and the last one is divided into three others: (1) According to the official documents from MEC and CNE, why can the observation and teaching supervised internships be conducted in remote classes? (2) Considering this decision, what do they understand as the role of supervised internships in Teacher Education courses? (3) Are they assuming that public schools are being able to implement remote classes? If so, (a) are the classes focused on the use of digital technologies? (b) are teachers and students having access to adequate equipment and internet connection? (c) are teachers and students having support to deal with their social contexts in terms of place to work and study, as well as emotional problems arising from fears of the disease, lack of money and food at home?

The first approved document concerning remote classes during physical distancing times was MEC Ordinance No. 343 issued on March 17, 2020. It "provides for the substitution of in-person classes for classes in digital media while the New Coronavirus - COVID-19 pandemic situation lasts." According to its first Article:

It is exceptionally allowed replacing in-person classes, in progress, by classes that use information and communication means and technologies, in a higher education institution that is part of the federal education system, which is dealt with in article 2 of the Decree $\mathrm{n}^{\circ}$ 9.235, of December 15, 2017 (BRASIL, 2020a, p. 1, our translation).

On the other hand, the information on the third paragraph is: "It is prohibited to apply the replacement, referred to in the caput, to Medicine 
and Health majors as well as to the professional practices of internships and labs of other majors" (emphasis added). Based on Article 1 and on the third paragraph of MEC Ordinance No. 343, it is possible to notice that they present different orientations for Medicine and Health majors as compared to other majors. While for the Medicine and Health majors, all the classes, including professional practices of internships and labs, would be suspended, the classes interrupted in other courses would be restricted to professional practices of internships and laboratory. In this case, we may argue that, in this document, it is implied that professionals from all majors, except the medical ones, may graduate by attending remote classes.

Two days later, on March 19th, Ordinance MEC No. 345 changed some paragraphs of this article in the decree. We highlight the changes made in the third paragraph: "It is prohibited to replace the classes referred to in the caput to professional internship and laboratory practices" (BRASIL, 2020b, p. 1 our translation). Medicine and Health majors were excluded from this paragraph and included in the fourth paragraph: "Specifically for the Medicine and Health majors, it is only authorized the replacement that is treated in the caput to theoretical-cognitive courses from the first to the fourth year of the specified major" (BRASIL, 2020b, p. 1 our translation. Emphasis added). If, in the previous ordinance, they had prohibited the replacement of all in-person courses of Medicine and Health majors by remote classes, in the new ordinance, the theoretical-cognitive courses could be remote. In this case, the professional internship of Medicine and Health majors is still prohibited in the remote mode.

On June 1st, 2020, CNE / CP Opinion No. 5/2020 was published in The Official Journal of the Union (DOU), providing the "Reorganization of the School Calendar and the possibility of considering non-classroom activities to fulfill the standard annual minimum hours due to the COVID-19 Pandemic." This document was approved two and a half months after the interruption of in-person classes.

Concerning this specific document (CNE/CP 5/2020), we now focus on subsection 2.15 which provides for Higher Education. While Article One of MEC Ordinance No. 343, previously explained, authorized remote classes for all the courses, except internships and laboratories, in Opinion CNE / CP 5/2020 they argue that: 
Even though this measure expands and allows the continuation of the suspended classes, it restricts the perspective of Technologies and methods and for virtual laboratories and interaction processes which could enable practical activities and internship programs in working places for certain areas and professional fields (BRASIL, 2020c, p. 17, our translation).

This specific document, therefore, states that it is necessary to extend the offer of remote classes to all courses, including internships and laboratories. However, there are two ideas in this excerpt that are important to analyze: (1) authorization of remote practical activities and internship; (2) authorization of remote practical activities and internship for certain areas and professional fields.

If, on the one hand, MEC Ordinance No. 343 prohibits remote practical activities and internship, on the other, the CNE/CP Opinion No.5/2020 argues that, in this case, students would be missing the opportunity to learn how to implement appropriate methodologies and technologies to new contexts. It seems that they are referring to students who attend different majors. However, in the last phrases of this Opinion's excerpt, the information is "[...] for certain areas and professional fields" (emphasis added). Among the fifteen recommendations for higher education, the fifth one defines what these "certain" areas and fields of professional practice would be: "[to] adopt non-classroom activities of practices and internships, especially to undergraduate and pre-service teacher majors" (BRASIL, 2020c, p. 18, our translation). The adverb especially used in this part of the Opinion could be replaced by "exclusively", since, throughout the document, there is no recommendation in this regard for other majors, such as the ones in the field of Health and Medicine, for example.

If the reason for remote classes for Teacher Education majors is to allow students to learn how to use methodologies and technologies, the Health and Medicine internships would not have to be suspended considering the same reason.

In February 2019, the Resolution No. 2.228/2019 by the Federal Council of Medicine (FCM) published in DOU "Defines the discipline of telemedicine as a way of providing medical services mediated by technologies" (BRASIL, 2019). In addition, in March, 2020, FCM issued a note recognizing telemedicine as "[...] the possibility of remote medical 
care to fight against COVID-19”. Considering such an orientation, doctors can make use of technologies to attend to patients in remote appointments. Therefore, Medicine and Health majors could also be included in the discussion of $\mathrm{CNE} / \mathrm{CP} 5 / 2020$ in relation to remote practical activities and internships.

Regarding the other discussions presented throughout subsection 2.15 of the Opinion, we highlight three possible reasons for remote theoretical and practical activities during isolation in Teacher Education courses. One of the reasons is a bureaucratic one - (1) course completion; and the other two are pedagogical reasons which are somehow interrelated - (2) experience with pedagogical practices based on the use of technologies; (3) basic education, where internships are carried out, is also offering remote classes.

In different parts of the document, they mention the need to offer remote activities to fulfill the course load: "higher education institutions may consider using distance education as an alternative to the pedagogical and curricular organization to replace 800 hours workload" (BRASIL, 2020c, p. 18, our translation). They give the same reason for the practical activities of the mandatory internships "[to] guarantee the possibility of course completion on time". Therefore, they intend to implement remote classes for bureaucratic reasons, course load fulfillment, which could be redefined considering the impacts and changes in societies due to pandemic isolation.

One of the pedagogical reasons for taking remote practical activities and internships is that undergraduate students are going to have the opportunity to implement pedagogical practices using technologies.

There is a lot of research on digital technologies and education (JEWITT, 2008; LANKSHEAR, 2003; NASCIMENTO, 2014; ROCHA; AZZARI, 2016; BATISTA SILVA, 2014). Nascimento (2014) argues that basic education students are connected to different digital technologies, such as personal computers, smartphones, and the internet. She also states that such digital technologies change the local spaces requiring that we revisit pedagogical practice theories. Based on these studies, we agree that it is important that Teacher Education courses offer the opportunity for future teachers to analyze the use of digital technologies, and identify the possibilities of using them in their pedagogical practices.

However, learning how to use digital technologies is not only about learning how to use their tools or resources. It is not enough to learn how to record a video or to create a discussion forum. Learning how to use digital 
technologies includes adopting a critical view of the digital technologies used in societies. Because of them, we have new spaces to interact in, such as, social networks and collaborative encyclopedias. In these spaces we are not only information consumers, but also, and mainly, information and knowledge producers (ALMEIDA DE SOUZA, 2020). As a consequence, we have to behave in an ethical way. It means that we have to acknowledge and take responsibility for the information and knowledge that we produce and share. It is important that we are aware of how responsible we are when defending one or another point of view (MENEZES DE SOUZA, 2011).

The third reason to justify remote practical activities and internships in Teacher Education majors is that there is " [...] a broad process of offering remote classes for basic education students [elementary, middle and high school]" (BRASIL, 2020c, p. 17, our translation). That is, it is assumed that basic education teachers are using digital technologies to teach and because of that the Teacher Education undergraduate students could join this experience.

On March 17th, classes at schools were suspended to avoid the new coronavirus pandemic progress. Shortly after, on March 31st, the National Education Council (CNE) answered some questions about teaching during the coronavirus pandemic. The questions were basically related to remote classes offering legitimacy, and whether such classes could be considered to guarantee the compliance with the workload. These answers would be the basis of the Opinion CNE/CP 5/2020, previously mentioned in this section, which refer to school calendar organization and minimum annual workload compliance. This Opinion was published on June 1st.

However, some schools started offering remote classes in April. Because of that, we can argue that authorities decided for remote classes based on the answers given by $\mathrm{CNE}$ on their website, not by an official document. In these answers, $\mathrm{CNE}$ argues that the Guidelines and Bases of National Education Law (LDB) (BRASIL, 1996) authorizes remote activities for students in basic education in emergency situations. There are some suggestions of remote activities, such as: digital media platforms, video, virtual platforms, social networks, television or radio programs, printed teaching material. CNE argues that the aims for adopting these solutions would be to avoid increasing inequalities, school drop-out and school failure.

Besides that, they say that the days in which the students have had remote classes could be considered to fulfill the workload. In these cases, 
state and municipal authorities and private institutions must ensure: adequate methodologies and resources; and effective participation and monitoring of students. If some institutions decide they are not going to have remote classes, they are supposed to organize their academic calendar in order to comply with the days and hours mandated by law.

One of the aspects mentioned in the Nova Escola magazine survey, mentioned in the previous section, is about emotional health. The answers showed that $66 \%$ of the teachers have had to leave work due to health issues. Sixty-eight percent (68\%) of them were affected by anxiety and $28 \%$ reported suffering or having suffered from depression by the time of the survey. When authorities proposed remote classes, they were considering that there were (only) two problems to be solved: preventing infection by the virus and avoiding increasing inequalities, school drop-out and school failure. Nevertheless, based on teachers' answers (how different would they be from the students' answers?), we can argue that remote classes may also cause other problems, such as emotional ones.

As for the bureaucratic/pedagogical aspects, teachers said that they were having trouble adapting to the remote classes structure. Besides that, $51.1 \%$ of teachers reported lack of preparation. They had not had any preparation from their networks or maintainers to work. Teachers also informed that students did not have electronic equipment. As a consequence, their access is limited not only to do the tasks, but also to contact with teachers. While in private schools $59 \%$ of students have participated in remote activities, in public ones, student participation is limited to $32 \%$. Apart from that, teachers complain about the high demand for results and for individual assistance to families.

The first orientations of CNE in March focused on the authorization of remote classes to fulfill the workload and to teach the planned contents. Somehow, they showed that they were worried about students learning when they called attention to the importance of ensuring adequate methodologies and resources and effective participation and monitoring of students. However, they did not mention other aspects that are also important and which were evident in teachers' answers for Nova Escola magazine survey - lack of equipment and limited access to remote classes, to mention some.

Neither CNE nor Nova Escola magazine surveys have considered other aspects that affect people who are members of groups from "south of quarantine". For Sousa Santos (2020, p. 15), these groups have something 
in common, they "suffer from a special vulnerability that precedes the quarantine and worsens with it." One example of these groups are the people who live in poor neighborhoods. They do not have or have very limited access to sanitation, water, electricity, health care etc. By living in these contexts, students not only have difficulties accessing remote classes for not having the equipment but may also develop physical and emotional health problems due to their social conditions.

How can we ensure that the way CNE Opinion and the other institutions are considering remote classes as a solution during the pandemic is not going to cause or deepen inequalities, school drop-out and failure for students from the "south of quarantine"? In the next section, we present the analysis of a proposal issued by the federal university in which the authors of this paper are faculty members. It is a Public Call that was based on the documents analyzed here: MEC Ordinance No. 343; MEC Ordinance No. 345; and CNE / CP Opinion No. 5/2020.

\section{A virus and local educational decisions}

On June 1st 2020, a video was posted on the official YouTube page of the Federal University of Sergipe, where the authors of this article work as professors. It was an announcement, made by the Dean of Undergraduate Studies, about a special semester in which the various departments could offer courses to the academic community, remotely, due to the COVID-19 pandemic. He mentioned that details about the proposal could be found on the Public Call that was issued on May 28th. The university posted an official note about the special semester on its website on May 29th. The Dean of Undergraduate Studies also gave an interview for a local News TV channel, making the announcement known by a wide audience.

The coordinator of the Board of Representatives of the English Majors, as well as the students' representatives received emails, WhatsApp messages, and phone calls immediately after the announcements. Students were eager for answers and details about the courses. Some were worried because they feared they could/would be excluded from that process, due to their poor access to the Internet and/or to good equipment; elements that are, after all, essential to enable students to attend classes remotely. In reality, students and teachers were unable to define the best path to follow. The university's various departments had not yet analyzed the proposal 
(Public Call N.12/2020/PROGRAD/UFS, 2020), which was based on what was issued by the Education Ministry/MEC: Ordinance No. 343 and Ordinance No. 345; and by the National Education Council/CNE: CP Opinion No. 5/2020, as for the measures higher education institutions had to take considering the current pandemic crisis.

The Department's Boards of Representatives for the Language Teaching Education Majors (English; Portuguese/English; Portuguese/ French; Spanish; and Portuguese/Spanish) held meetings to discuss this important and complex issue, which resulted in a document that is here discussed. The first big challenge to be faced was related to the extremely short deadline provided by the university, considering the crucial decisions the departments were expected to make. The Board of Representatives of the Department's English Majors (composed of 12 faculty and 02 students), of which the authors of this paper are members, met on June $4^{\text {th }}$, to analyze the university's proposal. After pondering the pros and cons of the document issued by the institution, the Board decided, unanimously, not to participate in the special semester, being contrary to the terms that were proposed in the Public Call No 12/2020/PROGRAD/UFS. A document was prepared and addressed to the Dean of Undergraduate Studies stating our position and concerns. What follows is the description of the main elements the Board highlighted in a document to justify its decision.

The first point presented was related to the understanding that such an important subject should have been discussed in a broader manner, not only by a small committee. The participation of the various departments' representatives - professors, undergraduate students, and the administrative staff - should have been considered, as well as a survey with all the university community should have been conducted. It was also pointed out that the deadline provided for the departments to analyze the university's proposal was not sufficient due to the complexity of the moment, when societies are facing a pandemic that has been affecting all of us, worldwide, as it has been argued along this paper. The Board understood that the university was probably trying to answer part of the society's and of the academic community's pressure as for a solution to the problem of having the beginning of the semester postponed, not to mention the pressure imposed by the government on public servants in general and more specifically, on educators, as previously discussed in this article. 
Due to the nature of the current crisis, however, it was pondered that any measures taken by the university should consider what Sousa Santos (2020) points out when talking about the impact of the pandemic of COVID-19, and the potential knowledge societies can build from this experience. The author mentions a common debate from the field of Social Sciences, which raises the following question that is connected to the concerns of the Board: "[...] whether the truth and the quality of the institutions of a given society are better known in situations of normality, of current functioning, or in exceptional situations, of crisis" (SOUSA SANTOS, 2020, p. 5, our translation). With that in mind, the analysis conducted by the Board intended to help our university to manage the challenges we are now facing, in this period of crisis, with caution, professionalism and social responsibility.

The second point was regarding a survey that was conducted by the university with the objective of finding out about the profile of its students as for their access (or not) to the Internet and to equipment that is required for them to attend classes remotely (notebooks, smartphones etc.). The results, however, were not available by the time the departments were asked to decide whether to join the new semester. The Board understood that the lack of that relevant piece of information could affect their judgment, which could lead to a situation of exclusion. It was highlighted that any debate about education should always consider that, and with the pandemic of COVID-19, situations of social inequality should now be viewed through magnifying glasses.

In the same local document, students' representatives also shared their concerns as for that possibility, when they mentioned that a considerable number of students have already been facing difficulties, on a regular basis, as for the points already mentioned. Besides poor Internet connection, some do not even have good equipment or even any equipment to prepare their homework assignments and/or to conduct research, let alone to attend remote classes. Moreover, to attend English language classes, which require the use of specific strategies and methodologies in order to achieve good communication among all involved in the teaching and learning process.

Added to that, the third and fourth points were related to a basic principle that must be part of the foundation of any educational action: the search for social inclusion. We stated our concern about the access of students who present any physical difficulties/disabilities that could, 
somehow, prevent them from attending remote classes. No information was provided by the university as for the number of students who would need special support, such as specific pieces of equipment and/or special tutoring.

In a broader sense, considering what has already been pointed out along this paper, schools and universities have been asked to change inperson to remote teaching practices and this process involves not only the adoption of digital technologies, but also appropriate teacher education. When the Board highlighted the need for faculty to be better prepared before any semester is offered, it was considered not only the development of technical skills but also, and mainly, that appropriate teacher education must focus on how to deal with remote education, problematizing its particularities, tools and methodologies. Even though the university had already started providing teachers with some sort of preparation (of the one-size-fits-all kind), the courses offered were not enough to help teachers be prepared to face the new reality. After all, it is not the case of just offering courses for all professors, neither transferring pedagogical practices that were applied to regular classes (in-person) into remote classes. On the contrary,

a long history of research into teachers' professional development suggests teachers gain most from professional development experiences that are not delivered by expertoutsiders and that are not one-size-fits-all, one-shot sessions on how to do something better. [...] Instead, research suggests what works includes things like sustained and supported opportunities to learn something new or to learn about something familiar more deeply, learning opportunities that are grounded in immediate teaching contexts, encouragement to change classroom and school practices in innovative ways, enacting social theories of learning to shape collaboration among fellow teachers, fluid leadership and expert roles within a professional learning group or space, and a conviction that what's being learned is going to be useful or beneficial to students [...] (KNOBEL; KALMAN, 2016, p. 3).

Another point of utmost importance was about the deadline proposed in the document for the departments to choose which course components to offer in the special semester, "considering the analysis of the pedagogical needs indicated by the various Boards of Representatives" 
(UFS, 2020, p. 3). The decision-making process, according to the Public Call, should consider two types of course components: 1. Elective theoretical components that hadn't been offered on a regular basis, and whose choice should consider students' demands/interests; 2. Mandatory theoretical components, mainly the ones with high index of failure. The objective was to provide students with the chance of regularizing their school records. The university proposal also stated that the course plans should indicate the number of professors involved, the pedagogical tools required, details about methodology, evaluation system, and any information considered necessary to the development of remote classes. The Board considered it was not feasible to answer the deadline proposed by the university (May 29th to June 09th) because that kind of analysis demands time to be conducted, considering the elements already highlighted in this text.

Not only methodological and technical issues were considered by the Board of Representatives in its analysis. Even though the proposal was not mandatory, it was understood that it provoked expectations in students, increasing the level of anxiety, mainly in the faculty members, due to reasons already pointed out: lack of time to prepare materials, to get appropriate teacher education, to adapt in-person methodologies to remote education; to make decisions as for which course components to offer; besides raising questions about whether or not all students would have the means to attend remote classes.

As stated in the document issued by the Board, the Central Students Directory (DCE) was also contrary to the terms proposed in the Public Call 12/2020/PROGRAD/UFS. The first point highlighted was that the university had not provided them with data about the survey conducted with students about their access to the Internet and to digital technologies. From their knowledge about the difficulties many students face on a regular basis, concerning those issues, it was crucial to know how many students would be excluded from the special semester. They had pointed out that many students already depended on the university structure to access the Internet to do research and to send their homework assignments to their professors. More than that, they were aware that some students needed to make use of computers from the university library, for instance. The DCE also considered that the deadline proposed in the document was not enough to ensure the quality of the teaching/learning process, pointing out the reasons already highlighted here regarding faculty concerns. 
Thus, considering the optative nature of the special semester; that the regular semesters would be offered as soon as possible; and considering the role public universities must embrace, of diminishing social inequality through education, the DCE understood that the offer of a special semester in the terms presented in the Public Call would not fully attend students' needs. On the contrary, the university could be contributing to the increase of social inequality if only students who present the means to attend remote classes would have the 'privilege' to choose whether or not to attend the special semester.

In view of what was exposed here, through the voices of faculty and students as documented locally, in the understanding that the public university must excel in decision-making based on the democratic exercise of dialogue, the Board of Representatives of the English Majors issued the document to be addressed to the Dean of Undergraduate Studies, stating their decision for not offering courses in the special period, with a request for further clarification regarding the points listed. This session was thus written based on such documentation.

\section{Final remarks}

As mentioned in the beginning of this article, since we always have to choose a path to follow, we also have to analyze the possibilities and the consequences of our choices. The path chosen by MEC and CNE was the one with remote classes and practical activities and internships. Such choice negatively affects both students from basic education and pre-service teachers. Thus, we understand as part of our job as applied linguists to question those decisions and their subsequent consequences locally, as we understand that educational policies are immersed in a broader political arena, now highly neoconservative.

There are many basic education public schools offering remote classes for their students based on the CNE orientations, that present remote classes as a solution to avoid increasing inequalities, school drop-out and school failure. As we all know, societies have been unable to solve social problems before the pandemic. Therefore, in the last few months, we have been facing the increase of poverty as well as physical and emotional health problems. Faced with this reality, authorities should ensure that people have access to adequate minimum resources to live - food, home, hospital, medicine - and 
access to remote classes - proper equipment and internet for both teachers and students; courses for teachers to learn how to use digital technologies or how to create specific content using video, television or radio programs or printed teaching material, as suggested by $\mathrm{CNE}$.

When the CNE authorizes pre-service teachers to have practical activities and internships during remote classes in basic education schools, it seems that they are ignoring or pretending not to see all the problems people, especially from "south of quarantine", are facing to survive and to have access to remote classes. That attitude reinforces how anti-intellectualism has played an important role in the Brazilian society. After all, are researchers and educators being heard on that matter? This attitude has echoed throughout the country and in different local policies, such as the case analyzed in the last section of this article. Should faculty accept the conditions of the call without questioning? What is our role as teacher educators in a public higher education institution? What should be the answer of public higher education institutions to this moment of crisis as for not promoting social exclusion? These are some of the points addressed in the local document discussed.

\section{Authors' contributions}

The three authors wrote sections 1 and 5 collaboratively. Ana Karina Nascimento authored section 2, Marlene Augusto de Souza authored section 3 and Maria Amália Façanha authored section 4 individually. The three authors read and reviewed all the sections.

\section{References}

ALMEIDA DE SOUZA, M. A. PIBID-UFS - Formação de Professores e o (não) lugar das tecnologias. In: MAYNARD, D. C. S.; COSTA, P. R. S. M. (Org.). Iniciação à docência e residência pedagógica na UFS: relatos, experiências e perspectivas. Recife: Editora Universidade de Pernambuco, EDUPE, 2020. p. 10-22.

BATISTA SILVA, S. Leitura digital na graduação em letras: uma experiência no Rio de Janeiro. In: TAKAKI, N.; MACIEL, R. F. (org.). Letramentos em Terra de Paulo Freire. Campinas, SP: Pontes Editores, 2014. p. 133-150.

BIMBATI, A. P. Qual é a situação dos professores brasileiros durante a pandemia? Pesquisa feita por NOVA ESCOLA mostra a experiência dos educadores nesse período, os desafios e as expectativas sobre o futuro. 2020. Available at: https://novaescola. org.br/conteudo/19386/qual-e-a-situacao-dos-professores-brasileiros-durante-apandemia?itm_campaign=newsletterprodutosabertos $>$. Access: July 25th, 2020. 
BRASIL. Lei de Diretrizes e Bases da Educação Nacional (LDB), n. 9.394, de 20 de dezembro de 1996. Estabelece as diretrizes e bases da educação nacional. Available at: http://www.planalto.gov.br/ccivil_03/Leis/L9394.htm. Access: August 2nd, 2020 .

BRASIL. Diário Oficial da União. Resolução No. 2.228/2019, de 26 de fevereiro de 2019. Revoga a Resolução CFM no 2.227, publicada no D.O.U. de 6 de fevereiro de 2019, Seção I, p. 58, a qual define e disciplina a telemedicina como forma de prestação de serviços médicos mediados por tecnologias, e restabelece expressamente a vigência da Resolução CFM no 1.643/2002, publicada no D.O.U. de 26 de agosto de 2002, Seção I, p. 205. Available at: https:/ /www.in.gov.br/web/ dou/-/ resolucao-n-2-228-de-26-de-fevereiro-de-2019-65864787. Access: August 2nd, 2020.

BRASIL. Ministério da Educação. Portaria no 343 de 17 de março de 2020. Dispõe sobre a substituição das aulas presenciais por aulas em meios digitais enquanto durar a situação de pandemia do Novo Coronavírus - COVID-19. Brasília, DF: Ministério da Educação, 2020a. Available at: https://www.in.gov.br/en/web/dou/-/portarian-343-de-17-de-marco-de-2020-248564376. Access: August 2nd, 2020.

BRASIL. Ministério da Educação. Portaria no 345 de 19 de março de 2020. Dispõe sobre a substituição das aulas presenciais por aulas em meios digitais enquanto durar a situação de pandemia do Novo Coronavírus - COVID-19. Brasília, DF: Ministério da Educação, 2020b. Available at: https://www.in.gov.br/en/web/dou/-/portarian-343-de-17-de-marco-de-2020-248564376. Access: August 2nd, 2020.

BRASIL. Conselho Nacional da Educação. Parecer CNE/CP n. 5/2020 de 1 de junho de 2020. Dispõe sobre a reorganização do Calendário Escolar e da possibilidade de cômputo de atividades não presenciais para fins de cumprimento da carga horária mínima anual, em razão da Pandemia da COVID-19. Brasília, DF: Ministério da Educação, 2020c. Available at: http://portal.mec.gov.br/ index.php?option $=$ com_docman\&view $=$ download $\&$ alias $=145011-$ pcp00520\&category_slug $=$ marco-2020-pdf\&Itemid $=30192$. Access: August 2nd, 2020.

CARROLL, L. Alice's Adventures in Wonderland. [S.l.]: Open Books Electronic Edition, 2007. [Originally Published by Macmillan \& Company, 1865].

DUBOC, A. P. M.; FERRAZ, D. de M. Reading Ourselves: Placing Critical Literacies in Contemporary Language Education. Revista Brasileira de Linguistica Aplicada, Belo Horizonte, v. 18, n. 2, p. 227-254, 2018. DOI: https://doi. org/10.1590/1984-6398201812277 
FORREST, S. Could the Social Distancing of COVID-19 Revolutionize Online Learning and Higher Education? Interview with prof. Bill Cope and prof. Mary Kalantzis, 2020. Available at: https://news.illinois.edu/view/6367/807485. Access: April 14th, 2020.

JEWITT, C. Multimodality and Literacy in School Classrooms. Review of Research in Education, [S.l.]: v. 32, n. 1, p. 241-267, 2008. DOI: https://doi. org/10.3102/0091732X07310586

KNOBEL, M.; KALMAN, J. Teacher Learning, Digital Technologies and New Literacies. In: (ed.). New Literacies and Teacher Learning. New York: Peter Lang, 2016. p. 1-20. DOI: https://doi.org/10.3726/978-1-4539-1823-4

LANKSHEAR, C. The Challenge of Digital Epistemologies. Education Communication and Information, [S.l.], v. 3, n. 2, p. 167-186, 2003. DOI: https//:doi. org.10.1080/14636310303144. Available at: https://www.researchgate.net/ publication/250889710_The_Challenge_of_Digital_Epistemologies. Access: August 2nd, 2020.

MENEZES DE SOUZA, L. M. T. Para uma redefinição de letramento crítico: conflito e produção de significação. In: MACIEL, R. F.; ARAÚJO, V. de A. (org.). Formação de professores de linguas ampliando perspectivas. Jundiaí: Paco Editorial, 2011. p. 7-38.

MIKS, J.; MCILWAINE, J. Keeping the World's Children Learning Through COVID-19, 2020. Available at: https://www.unicef.org/coronavirus/keeping-worlds-childrenlearning-through-covid-19. Access: May 4th, 2020.

NASCIMENTO, A. K. de O. O ensino de língua inglesa sob o viés dos letramentos digitais. In: ZACCHI, V.; STELLA, P. R. (org.). Novos Letramentos formação de professores e ensino de lingua inglesa. Maceió: EDUFAL, 2014. p. 52-74.

ROCHA, C. H.; AZZARI, E. F. Tecnologias digitais e educação crítica em língua estrangeira: um relato de experiência à luz dos letramentos. In: JESUS, D. M. de; CARBONIERI, D. (org.). Práticas de multiletramentos e letramento crítico: outros sentidos para a sala de aula de línguas. Campinas, SP: Pontes Editores, 2016. p. 157-182.

SOUSA SANTOS, B. A cruelpedagogia do vírus. Coimbra: Almedina, 2020.

STANLEY, J. How Fascism Works: The Politics of Us and Them. New York: Random House, 2018.

UNIVERSIDADE FEDERAL DE SERGIPE (UFS). Pró-Reitoria de Graduação. Edital N. 12/2020/PROGRAD/UFS, de 28 de maio de 2020. Chamada pública para oferta excepcional de componentes curriculares dos cursos de graduação da UFS, por meio remoto, durante período letivo especial. Available at: http:// 
prograd.ufs.br/uploads/page_attach/path/8505/Edital_PROGRAD_-_Oferta_ de_Componentes_e.pdf. Access: June 1st, 2020.

UNIVERSIDADE FEDERAL DE SERGIPE (UFS). Prograd explica o período letivo especial 2019.4. Available at: https://www.youtube.com/ watch?v=gdqP3KaZ_iQ\&t=17s. Access: June 1st, 2020.

WORLD HEALTH ORGANIZATION. WHO Coronavirus Disease (COVID-19) Dashboard, 2020a. Available at: https:/ / covid19.who.int/. Access: July 27th ${ }^{\mathrm{h}}, 2020$. WORLD HEALTH ORGANIZATION. Coronavirus disease (COVID-19) advice for the public, 2020b. Available at: https://www.who.int/emergencies/diseases/ novel-coronavirus-2019/advice-for-public. Access: July 27th, 2020.

Data de submissão: 30/8/2020. Data de aprovação: 12/2/2021. 